\title{
FENOMENA MITOS YANG BERKEMBANG DI MASYARAKAT POST MODERN PERSPEKTIF ISLAM
}

\author{
Nur Khosiah, Devy Habibi Muhammad \\ STAI Muhammadiyah Probolinggo \\ Email:nurkhosiah944@gmail.com,hbbmuch@gmail.com
}

\begin{abstract}
Abtrak
Masyarakat Indonesia adalah masyarakat majemuk dari Sabang sampai Merauke memiliki kearifan lokal tersendiri yang merupakan bagian dari kebudayaan masyarakat Indonesia. Masyarakat Indonesia mempunyai kepercayaan pada hal-hal tertentu yang terkadang tidak masuk akal tetapi terjadi dalam kehidupan nyata dikarenakan kepercayaan tersebut sudah melekat dalam kehidupan masyarakat. Hal ini yang kita sebut dengan mitos. Meskipun masyarakat sudah hidup di zaman modern dan di era digital tetapi mitos masih berkembang dalam masyarakat contoh wanita hamil jika jatuh harus merobek bajunya dan jika luka harus di obati dengan kotoran sapi (celethong), bayi yang baru di lahirkan ketika tidur disampingnya harus tersedia sapu lidi, gunting, cermin.jika ada orang meninggal perjaka/ perawan pemakamannya harus di payungi. Dalam tulisan ini penulis akan memaparkan berbagai fenomena yang berkembang di masyarakat melalui pengamatan dan dianalisis secara deskriptif berdasarkan perspektif Islam.
\end{abstract}

Kata Kunci: Mitos, Post Modern, Islam

\section{Pendahuluan}

anusia dilahirkan dalam keadaan fitrah dan tidak mengenal apapun setelah
dewasa mereka banyak belajar dari berbagai pengetahuan mulai dari
keluarga, sekolah-sekolah,lembaga kursus, pengajian, maupun pengalaman pribadi atau bermasyarakat. Hai inilah yang akan menumbuhkan pemikiran yang berbeda antara yang satu dengan yang lainnya sehingga banyak terjadi perbedaan-perbedaan dikalangan masyarakat baik dari segi pemikiran, kepercayaan, keyakinan, pendapat dan lain sebagainya, apalagi masyarakat Indonesia yang terdiri beribu-ribu pulau, suku bangsa, bahasa, adat istiadat, kepercayaan dan masih banyak lagi perbedaan yang di miliki bangsa Indonesia akan tetapi dengan semboyan Bhineka Tunggal Eka yang berarti berbeda-beda tetapi tetap satu jua meski banyak terjadi penjajahan di masa lalu akhirnya Indonesia bebas dari penjajah dengan satu kata "Bersatu"dan sampai saat ini dan sampai kapanpun kita sebagai masyarakat Indonesia harus tetap menjaga persatuan dan kesatuan Indonesia. 
Banyaknya ragam suku, bahasa, adat istiadat dan kebudayaan Indonesia ini yang menjadikan kekayaan Indonesia semakin melimpah sehingga membuat iri bangsa-bangsa lain. Keberagaman juga yang memunculkan banyaknya kepercayaan yang masuk ke Indonesia sehingga banyak hal yang tidak mutlak kebenarannya menjadi hal yang sangat penting di masyarakat. Mitos merupakan salah satu fenomena yang tidak bisa kita hindari keberadaannya, mitos berkembang dalam masyarakat Indonesia meski bangsa ini telah mengalami perkembangan yang begitu pesat dalam segala bidang. Di era digitalisasi mitospun tidak akan pernah tenggelam dan tidak juga akan punah dengan kemajuan zaman. Terbukti dalam masyarakat Indonesia fenomena mitos masih banyak dijumpai dan setiap daerah mempunyai mitos yang berbeda.Mitos merupakan suatu hal yang menceritakan kejadian di masa lampau dan di anggap benar terjadi oleh penganut cerita tersebut, yang para tokohnya adalah para dewa atau makhluk setengah dewa yang terjadi di dunia lain. Mitos berasal dari bahasa Yunani mithos yang berarti dari mulut ke mulut, atau dengan kata lain cerita informal suatu suku yang diteruskan dari satu generasi ke generasi berikutnya. ${ }^{1}$

Mitos merupakan salah satu hal yang berkembang dalam masyarakat dan sudah menjadi kepercayaan pada masing- masing daerah tempat tinggal masyarakat itu sendiri. Adapun mitos di setiap daerah tidak sama karena masyarkat antara daerah yang satu dengan yang lain memiliki mitos yang berbeda. Beberapa hasil pengamatan dapat diketahui bahwa tradisi ritual masyarakat secara sederhana dimanapun mereka berada, pasti memiliki tujuan tersendiri yang tentunya yaitu mendambakan kedamaian lahir dan batin, agar terhindar dari malapetaka. Bagi masyarakat ini sudah menjadi kebutuhan agar mereka tetap hidup yang bisa menyediakan adalah alam. Dengan kata lain ritualitas adalah tindakan keseimbangan antara diri dengan alam. Di Indonesia mitos di bagi menjadi dua macam berdasarkan tempat asalnya, yakni asli Indonesiadan yang berasal dari luar negeri, terutama dari India, Arab, dan sekitar Laut Tengah. ${ }^{2}$ Keberadaan mitos di Indonesia telah menjadi bagian dalam kehidupan masyarakat kolektif mitos. Oleh karenanya, tidak jarang mitos menjadi sistem berfikir ataupun menjadi pedoman bagi suatu masyarakat dalam bertindak dan bertutur. ${ }^{3}$

Pada Masyarakat Pandhalungan mitos masih di percaya dan warisan dari nenek moyang, antara percaya tidak percaya dalam masyarakat masih melaksanakan

\footnotetext{
${ }^{1}$ Christensen, P. The "Wild West": The Life And Death Of A Myth (Southwest Review, .2008), 310.

${ }^{2}$ Danandjaja, J, Folklor Jepang Dilihat Dari Kacamata Indonesia(Jakarta: Pustaka Utama Grafiti, 1997)

${ }^{3}$ Andalas. E.F, Dampak dan Fungsi Sosial Mitos Mbah Bajing Bagi Spiritual Masyarakat Dusun Kecopokan Kab.Malang Jawa Timur (Jurnal Puitika Volume. 13 No. 1April 2017).
} 
apa yang menjadi aturandalam mitos tersebut karena jika tidak melaksanakannya akan menimbulkan petaka bagi yang mengalami fenomena tersebut. Dalam pandanga islam mitos di anggap hal yang tidak sesuai denga ajaran Islam meski dalam Islam ada juga hal-hal yang gaib dan tidak dapat di rasionalkan. Di dalam ajaran Islam semua penciptaan alambeserta isinya ini hanya ada satu pencipta yaitu Allah SWT. Akan tetapi dalam mitos belun jelas dasarnya, yang jelas apa yang di percayai dalam mitos adalah dari para pendahulu nenenk moyang kita. Penulis tertarik untuk mengamati dan mendeskripsikannya sebab sepanjang perubahan zaman, dari masa ke masa, dari waktu ke waktu, hingga sampai pada saat ini, mitos tetap di percaya dalam masyarakat akan membawa hal buruk jika tidak dilaksanakan apa yang menjadi syarat dalam sebuah fenomena mitos tertentu,maka mitos tetap dipertahankan dan di lestarikan eksistensinya dalam masyarakat meski terkadang sangat tidak masuk dalam akal fikiran manusia.

\section{Fenomena Mitos, Dampak Dan Pengaruhnya Bagi Masyarakat}

Bangsa Indonesia tercipta sebagai bangsa yang memiliki kekayaan yang tak ternilai baik dari alamnya, sukunya, bahasanya, budayanya, adat istiadatnya sehingga siapapun orangnya akan terpukau melihat keindahan alam Indonesia yang membentang dari sabang sampai merauke. Masyarakat Indonesia memiliki beriburibu pulau mulai dari pulau yang terbesar di antaranya pulau Jawa, Kalimantan, Sulawesi, Sumatera, Papua sampai pulau kecil seperti Pulau Karamean, Talango, Gili dan pulau- pulau kecil lainnya yang bertebaran di wilayah Indonesia. Pulau Jawa salah satu pulau terbesar di Indonesia yang dahulunya memiliki banyak kerajaan besar, ada kerajaan Hindu, Kerajaan Budha, dan ada pula kerajaan Islam pertama di pulau Jawa yaitu kerajaan Demak. Pulau Jawa memiliki nilai kharismatik tersendiri terutama bagi masyarakat jawa baik itu masyarakat Jawa Barat, Jawa Tengah, maupun Jawa Timur yang semua masyarakatnyabaik kalangan atas maupun kalangan bawah mempunyai fenomena mitos tersendiri dan tentunya berbeda antara daerah yang satu dengan daerah yang lain itulah salah satu kekayaan Indonesia yang tidak bisa dipungkiri dan tidak pula bisa diabaikan keberadaannya. Masyarakat Jawa Timur yang terkenal dengan pantai utaranya memiliki banyak mitos yang berkembang. Dan banyak budaya yang masuk melalui jalur perdagangan laut sehingga semakin bertambah keberagaman budaya yang masuk ke masyarakat pantai utara Jawa Timur khususnya masyarakat Pandhalungan.

Masyarakat Pandhalungan adalah masyarakat yang hidup di daerah pantai utara Jawa Timur dan memiliki berbagai fenomena mitos yang berkembang dalam masyarakatnya dan sampai saat inipun masih di percaya dan di patuhi oleh masyarakat setempat sebagai warisan leluhur yang apabila mengabaikannya akan 
terjadi petaka pada diri dan keluarganya antara lain: Mitos pertama,jika ada perawan yang ingin cepat menikah harus minta bedak dan bunga dari pengantin baru. Kedua, jika ada wanita hamil jika jatuh harus merobek bajunya dan jika luka harus di obati dengan kotoran sapi (celethong), yang bertujuan untuk menolak bala' atau celaka bagi diri dan keluarga yang lainnya.Ketiga,jika ada gerhana bulan harus masuk kolong ranjang, yang tujuannya agar anak dan ibunya selamat. Keempat, bayi yang baru di lahirkan ketika tidur disampingnya harus tersedia sapu lidi, gunting, cermin. Yang tujuannya agar si bayi tidak terganggu oleh makhluk halus. Kelima, jika anak kecil sering kencing ketika tidur (ngompolan), mesti diolesi kulit kaki ayam yang sudah disembelih yang tujuannya agar anak tersebut tidak kencing lagi ketika tidur.

Keenam, Jika ada ibu yang sedang menyusui anaknya harus meletakkan bawang putih di pakaian dalamnya (bra) yang tujuannya agar si ibu dan bayinya tidak di ganngu oleh makhluk halus. Ketujuh, Jika ada gerhana matahari/bulan yang punya pohon harus di pukul dengan gagangnya clurit dan sapu lidi dengan tujua agar buahnya lebat dan pohonya tidak terkena penyakit. Kedelapan, jika ada orang meninggal perjaka/perawan pemakamannya harus di payungi yang tujuannya menjadi pembeda bahwa yang meninggal itu masih perawan/ perjaka. Kesembilan, jika ada orang meninggal pada tanggal wage dalam kelender jawa pemakamannya harus ditanami pohon pisang yang bertujuan agar dalam keluarganya tidak diajak meninggal (nggondhol). Kesepuluh, jika ada ibu hamil maka ayah bayi tidak boleh mengantongi apapun dalam saku pakaiannya hal ini jika di lakukan akan berakibat si bayi akan menderita penyakit hernia (lengser). Kesebelas, tidak boleh membunuh hewan apapun jika tidak terpaksa karena di khawatirkan akan mengganggu proses kelahiran atau si bayi dapat menyerupai hewan tersebut.

Dari hal diatas, menunjukan bahwa sebagaian besar masyarakat Indonesia masih melaksanakannya karena mitos mempunyai makna tersendiri bagi masyarakat pendukungnya sebab mitos memiliki fungsi dalam kehidupan sosial budaya diantaranya: 1) melestarikan simbol yang memiliki makna mendalam serta menjelaskan fenomenayang di hadapinya. 2) sebagai pegangan dan kepercayaan bagi masyarakat pendukungnya untuk membina kesetiakawanan sosial yang tinggi bagi para pendukungnya. 3) sarana pendidikan yang efektif untuk menanamkan dan mengukuhkan nilai-nilai kearifan lokal serta pemikiran maupun pengetahuan tertentu untuk merangsang kreativitas dalam berfikir. Sedangkan menurut Malinowski fungsi utama mitos bagi adalah mengungkapkan, mengangkat, dan merumuskan kepercayaan, melindungi dan memperkuat moralitas, menjamin efisiensi ritus, serta memberikan peraturan-peraturan praktis untuk menuntun manusia. 


\section{Dampak Mitos Bagi Masyarakat}

Dalam kehidupan masyarakat Pandhalungan meyakini bahwasannya jika tidak melakukan hal-hal yang tersebut di atas akan berdampak negatif pada diri orang yang mengalaminya ataupun pada keluarganya.Pertama,jika ada seorang wanita sudah cukup umur (usia 25 tahun ke atas)kemudian lama belum ketemu pasangan hidupnya maka oleh keluarganya terutama orang tuanya dia disarankan untuk meminta bedak dan bunga dari pengantin baru, agar wanita ini lekas bertemu dengan pasangan hidupnya jika wanita ini tidak segera bertemu dengan pasangan hidupnya berdampak orangtua dan keluarganya merasa tertekan dan malu dengan masyarakat sekitarnya karena anak mereka belum mendapatkan jodohnya sedangkan pada wanita itu sendiri merasa tidak nyaman dengan masyarakat sekitarnya apalagi jika dia tidak mempunyai aktifitas tertentu yang dapat menghibur perasaannya. Maka mitos untuk meminta bedak pengantin baru sering di percaya akan lekas mendapatkan pasangan hidup.

Kedua, jika ada wanita hamil dan jatuh dari sepeda/ motor ataupun tersandung ketika berjalan sampai jatuh ke tanah, dia harus merobek bajunya atau pakaian dalamnya, dan jika ada luka harus di obati dengan kotoran sapi (celethong), yang bertujuan untuk menolak bala'. Dampaknya bagi masyarakat penganutnya jika tidak melakukan hal tersebut di atas akan berakibat keguguran atau hal buruk lainnya. Masyarakat sudah terun-temurun mempercayai mitos ini sehingga generasi mudapun tetap mengikutinya meski tidak rasional. Ketiga jika ada gerhana bulan harus masuk kolong ranjang dengan mengigit genteng pecah (kereweng) yang tujuannya agar anak dalam kandungan beserta ibunya selamat tidak kekurangan apapun. Secara akal jika kita menyikapi hal ini tentunya sama sekali tidak logis yang rasanya memberatkan wanita hamil, akan tetapi mitos inipun banyak juga generasi muda melaksanakanya agar selamat sebab mitos ini sudah turun- temurun.

Keempat,bayi yang baru di lahirkan ketika tidur disampingnya harus tersedia sapu lidi, gunting, cermin. Yang tujuannya agar si bayi tidak terganggu oleh makhluk halus. Percaya tidak percaya banyak ibu muda yang mengikuti hal ini meski banyak juga yang menyangkal karena khawatir kelupaan sehingga berbahaya bagi anak dan ibunya. Akan tetapi bagi masyarakat penganutnya mempunyai dampak internal yaitu timbul banyak pertanyaan dalam dirinya, Iapun akan mencari jawabannya akan tetapi jawaban itu secara akal tidak akan memuaskan bagi dirinya sehingga diapun mematuhinya. Secara sosial akan dijauhi tetangga dan akan menjadi gunjingan masyarakat karena dianggap tidak tunduk dan patuh dengan aturan yang sudah ada ribuan tahun yang lalu. 
Kelima, jika anak kecil sering kencing ketika tidur (ngompolan) di kasur, ini bisa diolesi kulit kaki ayam yang sudah di sembelihyang bertujuan agar anak tersebut tidak kencing lagi ketika tidur. Kondisi ini berdamapak pada kepribadian seorang anak tersebut jika sering "Ngompol" dampaknya dia akan malu dan tertekan oleh keluarganya. Disamping itu juga akan merepotan keluarganya. Sedangkan pada sisi yang lain si anak akan mendapat hadiah hinaan dan gunjingan keluarga serta tetangganya. Untuk itu orang tua yang memiliki anak Ngompolan tentu akan mengikuti hal ini meski sangat tidak rasional, yang seharusnya anak seperti ini di bawah ke dokter akan tetapi malah di olesi kulit ayam yang belum tentu steril apa tidak dan justru akan menimbulkan ha-hal yang tidak di inginkan tapi itulah salah satu warisan keluarga dan masyarakat sekitar. Keenam,jika ada ibu yang sedang menyusui anaknya di harus meletakkan bawang putih di pakaian dalamnya (bra) yang tujuannya agar si ibu dan bayinya tidak diganggu oleh makhluk halus. Bahkan masyarakat mempercayai hal ini jika menyusui bayinya mereka selalu membawa bawang putih dalam pakaiannya terutama di letakkan di pakaian. Ini berdampak jika tidak melakukan hal ini akan di marahi oleh orang tuanya dan anggota keluarga yang lainnya.

Ketujuh, jika ada gerhana matahari atau pun bulan masyarakat yang mempunyai pohon buah-buahan contohnya, mangga, sawo, jambu air dll, pohon itu harus dipukul dengan gagangnya clurit atau sapu lidi, agar buahnya lebat dan pohonya tidak terkena penyakit. Masyarakat mempercayai bahwa dengan melakukan itu buahnya akan lebat meski banyak juga sekarang ini pohon buahbuahan yang ingin lebat buahnya diberi pupuk dan juga obat agar lekas berbuah namun banyak juga masyarakat yang melakukannya denga memukul pohon tersebut dengan gagang clurit ataupun sapu lidi.Kedelapan, jika ada orang meninggal dunia perjaka/ perawan maka pemakamannya harus dipayungi yang tujuannya menjadi pembeda bahwa yang meninggal itu masih perawan/ perjaka dan bagi masyarakat pendukungnya si mayit membutuhkan payung untuk memayungi dirinya sebab si mayit belum merasakan kebersamaan dengan seorang suami/istri sehingga di kalangan masyarakat hal ini harus dilaksanakan karena dinilai sakral sehingga jika tidak melaksanakan ini akan mendapak bala' bagi keluarga si mayit.

Kesembilan, Masyarakat mempercayai jika ada orang meninggal pada pasaran wage dalam kelender Jawa pemakamannya harus ditanami pohon pisang yang bertujuan agar dalam keluarganya tidak diajak meninggal (nggondhol) meski kita sebagai umat Islam sudah menyakini bahwa umur seseorang hanya Allah yang Maha Mengetahui akan tetapi mitos ini masih kental sekali dalam 
masyarakat.Kesepuluh, jika ada ibu hamil tidak boleh mengantongi sesuatu apapun di dalam saku bajunya karena ini nanti akan berakibat si bayi akan menderita penyakit hernia. Dan masyarakat pendukungnya ini akan mematuhinya agar tidak terjadi hal-hal yang tidak di inginkan. Kesebelas, bagi masyarakat jika ada ibu hamil sang suami atau si ibu hamil tidak boleh membunuh hewan apapun karena dapat mengganggu proses kelahiran dan dapat juga si bayi jika sudah lahir menyerupai hewan yang di bunuhnya.

\section{Pengaruh MITOS BAGI MASYARAKAT}

Dari berbagai fenomena mitos yang ada dalam masyarakat mempunyai pengaruh yang sangat kuat dalam kehidupan sehari-hari antara lain di jadikan nilai-nilai budaya yang harus ditaati keberadaannya oleh masyarakat, sebagai aturan dan norma dalam masyarakat yang merupakan warisan keluarga yang harus di jaga dan dilestarikan, sebagai penghormatan terhadap kepercayaan leluhur meski tidak rasional akan tetapi untuk menjaga generasi dari marabahaya. Menjadi penyeimbang antara alam dan manusia.

\section{Konsepsi Pola Pikir Masyarakat Post Modern}

Manusia adalah makhluk sosial yang saling membutuhkan antara yang satu dengan yang lainnya. Kebutuhan antara yang satu dengan yang lain juga tidak akan sama, karena manusia adalah makhluk paling unik, yang semuanya itu anugerah terindah yang Allah SWT berikan pada manusia. Bumi yang ditempati ini semakin tua umurnya perkembangan dan kemajuan tehnologi dari masa ke masa semakin mengalami kemajuan yang pesat dan tentunya mengalami perubahan dari berbagai bidang kehidupan, begitu juga pada lingkungan sekitar, ada masyarakat primitif, ada masyarakat modern dan ada juga masyarakat postmodern. Menurut beberapa para ahli seperti Louis Leahy, postmodernisme merupakan pergerakan gagasan atau ide yang menggantikan gagasan atau ide-ide zaman moder. ${ }^{4}$ Hal yang sama dikemukankan oleh Emanuel, mengungkapkan bahwa postmodernisme termasuk segala daya upaya yang dimaksudkan untuk mengevaluasi paradigma masyarakat modern. ${ }^{5}$ Sedangkan menurut Ghazali dan Effendi, postmodernisme sebagai upaya untuk meneliti dan mengoreksi modernisme yang sebelumnya telah muncul dan tidak terkendali. ${ }^{6}$

\footnotetext{
${ }^{4}$ LouisLeavy, Manusia Sebuah Misteri Sintesa Filosofis Makhluk Paradoks (Gramedia :Jakarta, 1985).

${ }^{5}$ EmanuelWora, Perenialisme: Kritik Atas Modernisme Dan Postmodernisme Kanisius Yogyakarta, 2006).

${ }^{6}$ Ghozali Abd Muqith \&Djohan Effendi, Merayaka Kebebasan Beragama: Bunga Rampai menyambut 70 tahun Djohan Effendi: (Buku Kompas Jakarta. 2009)
} 
Dari pernyataan di atas mengemukakan bahwa masyarakat postmoden menginginkan segala sesuatunya lebih baik dari sebelumnya sebab masyarakat modern dianggap masih kurang mampu menjawab tantangan pola hidup yang berkemajuan seperti fenomena kehidupan saat ini. Masyarakat postmodern juga mempercayai bahwa kebenaran yang bersifat subyektif berdasarkan pada pandangan bahwa kebenaran adalah sebuah perspektif kemungkinan benar akan tetapi bukan hal yang sebenarnya. Dalam sudut pandang yang berbeda tentu akan timbul juga nilai kebenaran atau nilai kesalahan yang berbeda pula. Darmawan lebih lanjut menjelaskan bahwa, bisa saja semuanya jadi benar, dikarenakan kebenaran adalah perspektif, atau tergantung dari sudut mana seseorang itu memandangnya, dan juga tergantung sudut pandang iman agama masing-masing. Selain berdasar pada perspektif, masyarakat postmo juga menekankan bahwa kebenaran itu adalah kombinasi semua kebenaran yang ada. Sedangkan menurut Stanley J.Grenz memandang postmodern membawa corak yang negative karena menolak pemikiran modernisme. Hal ini merupakan perpecahan radikal dengan menekankan dan memasukkan pola pikir masa lalu dan telah merusak pola pikir generasi kakinian. Karena pokok pemikiran postmodern adalah mengedepankan relativisme dan menentukan kebenaran. Dalam hal ini penganut agama Kristen juga memandang hal yang sama sebagaimana kaum postmo bahwa kebenaran adalah sesuatu yang relative. $^{7}$

Ciri khas posmodernisme adalah ketiadaan pedoman untuk mengontrol segala sesuatu. Meskipun posmodern dalam masyarakat bermacam-macam bentuknya, mereka sama-sama sepakat bahwa tidak ada fokus atau titik berpedoman. Tidak ada lagi standar umum yang dapat digunakan untuk mengukur, menilai atau mengevaluasi konsep-konsep dan gaya hidup tertentu. Tidak ada kekuasaan yang absah dan berlaku untuk semua. Titik pusat sudah bergeser, masyarakat diibaratkan sekumpulan barang-barang yang beraneka ragam macamnya. Unit-unit sosial yang lebih kecil hanya disatukan secara geografis. ${ }^{8}$ Masyarakat postmodernisme pola pikir yang dikembangkan yaitu dengan menolak penekanan kepada penemuan hal-hal yang ilmiah melalui metode sains, yang merupakan fondasi intelektual dari modernisme untuk menciptakan dunia yang lebih baik. Masyarakat post modern menginginkan sesuatu yang dia percayai kebenaranya tanpa menunjukkan obyek yang jelas.Maka dapat disimpulkan bahwa masyarakat postmodernisme merupakan masyarakat yang mempunyai suatu ide baru yang menolak teori pemikiran atau pengembangan

\footnotetext{
${ }^{7}$ Darmawan,I.P.A , Pendidikan Kristen di Era Postmodern (STT Simpson,2016), 37-46

${ }^{8}$ Abdul Mukti Ro'uf,Postmodern:Dampak Dan Penerapannya Pada Studi Islam(Jurnal Studi Keislaman Volume 19 no 1 juli 2019)
} 
ide/gagasan yang telah ada sebelumnya yaitu paham modernisme.Masyarakat postmodern yang mencoba untuk memberikan kritikan ataupun saran terhadap modernisme yang dianggapnya telah gagal dan mempunyai tanggung jawab terhadap kehancuran martabat manusia merupakan pergeseran ilmu pengetahuan dari pemikiran modern yang berdasarkan penemuan ilmiah menuju pada suatu ide yang baru yang dibawa oleh postmodernisme itu sendiri. ${ }^{9}$

Berdasarkan berbagai ciri menonjol yang telah diungkapkan di atas bahwasannya masyarakat postmodern merupakan masyarakat yang mempunyai pola pikir yang bersifat subyektif bahwa kebenaran itu belum tentu hal yang sebenarnya tetapi mungkin juga benar. Mereka juga berpandangan bahwa kebenaran itu relative, dapat berubah sesuai dengan konteks, dan dapat berganti dengan gagasan baru, yang dianggap relevan dan efektif dari pada gagasan sebelumnya yang sudah ada. Dalam mengarungin roda kehidupan tentunya masyarakat postmodern menginginkan kehidupan yang lebih baik dari sebelumnya, dengan pola pikir yang tentunya akan berorientasi ke depan bagaimana segala sesuatunya dapat lebih baik dari sebelumnya.

\section{Mitos Dalam Pandangan Masyarakat Postmodern}

Pengalaman manusia lebih bersifat dinamis dan berkembang seiring perkembangan masyarakat, pada umumnya mitos di kembangkan untuk menanamkan dan mengukuhkan nilai-nilai budaya, pemikiran maupun pengetahuan tertentu. Menurut Hidayat bahwasannya dalam kehidupan sehari-hari, masyarakat postmodern dengan berbagai bentuk dan raut muka serta karakternya telah nyaris merasuk di segala bidang kajian ilmu, antropologi, sosiologi, komunikasi, administrasi, ekonomi, politik, bahasa dan sastra, maaupun seni. Berbagai teori pemikiran postmodern pun lahir. Dalam wilayah sosiologi, kajian tentang postmodernbaru menemukan bentuk dan kematangannya pada rentang waktu antara tahun 1960 hingga 1980 -an. ${ }^{10}$

Masyarakat postmodern pada awalnya merupakan reaksi terhadap modernisme. Masyarakat postmodern merujuk pada berbagai bentuk seni, kebudayaan, dan intelektual yang telah kehilangan hirarki atau prinsip kesatuan serta bertautan sehingga sulit membedakannya dengan parodi, syarat dengan kompleksitas ekstrim, kontradiksi, ambiguitas, perbedaan. Pemikiran teori postmodern dalam filsafat dan analisis kebudayaan serta masyarakat telah memperluas arti penting teori ini dan menjadi titik pusat berbagai gerakan untuk mengevaluasi sistem nilai Barat yang berlangsung sejak tahun 1960-an. Berdasarkan hal ini masyarakat postmodern

\footnotetext{
9 A. Sudrajat, Pemikiran Postmodernisme Dan Pandangannya Terhadap Ilmu Pengetahuan.(Jurnal filsafat Vol 28 No1, 2018), 33

${ }^{10}$ Hidayat, Menimbang Teori-Teori Sosial Postmodern:Sejarah, Pemikiran, Kritik,Dan Masa Depan Postmodernisme(Journal Unban Sociology.Vol 2 No.1,2019), 2-6
} 
selanjutnya menggunakannya untuk menggambarkan seluruh gerakan, terutama dalam seni, musik dan sastra untuk menentang modernisme khususnya dengan dilahirkannya kembali unsur-unsur dan teknik tradisional. Maka dapat diketahui pandangan masyarakat postmodern tentang mitos tidak lagi dipahami sebagai hal yang menyesatkan akan tetapi nilai budaya yang harus tetap dijaga dan di lestarikan keberadaannya. Mitos dianggap mengandung nilai positif karena membawa norma yang baik sehingga masyarakat pendukungnya selalu mentaatinya. Bukan hanya masyarakat pendukung yang mentaatinya, masyarakat yang awalnya menolak mitos akhirnya dapat terpengaruh dengan doktrin mitos yang berkembang di kalangan masyarakat. $^{11}$

Pada permasalahan sebelumnya masyarakat modern yang begitu mengedepankan rasio dan kecanggihan tehnologinya akan tetapi mereka di anggap belum sanggup menangani masalah moralitas, budaya, sosial dan degradasi lainnya. Sesungguhnya kritis postmodern terhadap situasi masyarakat modern yang paling mendasar diantaranya desentralisasi, deferensiasi, pluralisme, dekontruksi atau pula pada sebuah tatanan yang sudah ada.Tema-tema inilah yang sebenarnya memberi peluang baru munculnya berbagai mitos yang ada dalam masyarakat.Masyarakat postmodern mempercayai mitos dapat mengukuhkan norma-norma yang ada dalam masyarakat karena dipercaya dapat menciptakan kedinamisan dalam masyarakat pendukungnya dan masyarakat umum lainnya sesuai dengan mitos yang berkembang dalam masyarakat tersebut. Mitos di anggap tradisi budaya yang harus dijaga keberlangsungannya di dalam masyarakat. Mitos di anggap penolak bala' dari segala marabahaya dan mendatangkan kedamaian hati dari kekhawatiran ataupun kegelisahan yang mereka alami. ${ }^{12}$

\section{Menelaah Mitos Dalam Perspektif Islam}

Mitos merupakan suatu hal yang masih di percaya dalam masyarakat dan masyarakat pun melaksanakan apa yang menjadi kepercayaan di daerah tersebut. karena di khawatirkan akan terjadi sungguh apabila mereka tidak melaksanakannya. Jika ditinjau dari perspektif Islam hal ini sama sekali tidak sesuai dengan ajaran islam yang di bawah oleh Rosulullah SAW. Menghadapi dua zaman baik itu modern maupun postmodern diperlukan berbagai cara bagaimana mengukuhkan dan meneguhkan kembali prinsip-prinsip yang mendasar berdasarkan pada Al-qur'an dan Hadist, sehingga semua pola pikir dan praktek dalam kehidupan sehari-hari kita

\footnotetext{
${ }^{11}$ Hidayat, Menimbang Teori-Teori Sosial Postmodern:Sejarah, Pemikiran, Kritik,Dan Masa Depan Postmodernisme...,2-6.

${ }^{12}$ Budiman.A, Implementasi Postmodern Dalam Pendidikan Ainur Rahman Hidayat(Jurnal Filsafat Vol. I, No. 1, 2017), 17-18
} 
sandarkan pada ajaran Islam.Seperti yang telah di sebutkan bahwasannya seorang wanita yang ingin lekas bertemu dengan pasangan hidupnya harus minta bedak dan bunga pada saat acara di pinang oleh seorang laki-laki (lamaran) atau pada pengantin baru. Jika ditinjau dari perspektif Islam hal ini tidak sesuai karena ada tiga hal yang tidak bisa manusia itu merubahnya yaitu jodoh, rizqi dan kematian. Jika di sandarkan pada rasio bolehlah karena itu semua termsuk salah satu usaha agar jodohnya segera datang tapi jangan sampe menyakini jika minta bedak atau bunga jodohnya akan segera datang.

Selain itu ada juga mitos wanita hamil jika jatuh harus merobek bajunya dan jika luka harus diobati dengan kotoran sapi (celethong), yang bertujuan untuk menolak bala' atau celaka bagi diri dan keluarga yang lainnya.dalam ajaran Islam dalam hal ini justru sangat bertolak belakang bila aurat kita terbuka seharusnya di tutupi bukan malah di robek meski itu pakaian dalamnya dan apabila terluka harus segera di strerilkan dari debu atau kotoran yang menempel agar tidak infeksi, sebab dalam ajaran Islam cinta kebersihan itu sebagian dari iman dan semua musibah adalah kehendak Allah SWT semata. Selanjutnya contoh lain jika ada gerhana bulan harus masuk kolong ranjang, yang tujuannya agar anak dan ibunya selamat. Dalam perspektif Islam hal ini sangat jauh dari kebenaran Islam.

Dalam ajaran Islam jika ada gerhana bulan di anjurkan/ di sunnahkan untuk melaksanakan sholat sunnah dan mandi malam untu menyucikan diri agar banyak energi positif yang masuk bukan masuk ranjang dan bersembunyi, ini justru akan memberatkan si ibu sudah perutnya besar lalu masuk ke kolom ranjang, Allah SWT tempat berlindung bagi semua makhlukNya. Ada juga mitos lain jika mempunyai bayi yang baru di lahirkan ketika tidur disampingnya harus tersedia sapu lidi, gunting, cermin agar tidak di ganggu mahluk halus. Secara rasio ini sangat membahayakan bagi si bayi misalkan si bayi tengkurap akan berakibat fatal jika si Ibu atau yang menjaganya teledor tidak mengawasinya sedangkan di tinjau dari perspektif Islam ini tidak di benarkan karena manusia adalah makhluk mulia tidak mungkin sesuatu yang gaib akan mengganggu jika dalam rumah tersebut dalam kesehariannya di lantunkan ayat-ayat al-Quran.

Dalam perpsektif Islam mitos kemungkinan benar kemungkinan salah karena, karena segala sesuatu wajib disandarkan semua pada Sang Pencipta alam semesta ini dan bukan pada hal-hal yang bersifat mithologis. Kebanyakan orang percaya pada mitos itu dikarenakan warisan lisan dari keluarga atau masyarakat setempat yang mempercayai kejadian tersebut ataupun ada seseorang yang pernah mengalaminya. Sehingga agar tidak mengalami hal yang sama, masyarakat mematuhi mitos tersebut. Secara umum masyarakat didominasi oleh mitos tentang kemurkaan alam. Maka 
kesepakatan yang mereka putuskan selalu berhubungan dengan kelestarian alam. Makhluk gaib/tidak nampak oleh mata keberadaannya memang ada tapi dalam dunianya sendiri, beda dengan dunia manusia. Karena mereka juga adalah ciptaan Allah SWT dan berkewajiban untuk beribadah sama juga dengan manusia yang di perintahkan menjalankan semua perintah-Nya dan menjauhi segala laranganNya.

Dengan demikian fenomena mitos tidak wajib diyakini kebenarannya terutamabagi umat Islam,namun yang wajib diyakini adalah kebenaran dari Allah SWT bukan dari hal-hal lain karena semua hal dalam kehidupan ini adalah milik Allah SWT bukan milik siapapun, meski dalam Islam tidak melarang umatnya untuk menghormati warisan leluhur kita contohnya di setiap daerah ada mitos yang berlaku seperti di Jawa Tengah adanya tradisi grebek maulud yaitu untuk memperingati kelahiran Nabi kita Muhammad SAW dan masyarakatpun berebut makanan atau tumpeng yang telah di sediakan oleh pihak kerajaan pada waktu itu yang sampai sekarang setiap tahun juga melaksanakan grebek maulud. Akan tetapi sebagai makhluk ciptaan Allah SWT tidak dibolehkan menyakininya bahwa yang membawa berkah adalah tumpeng yang bentuknya besar dan tinggi itu.

Berdasarkan uraian di atas dalam perspektik Islam tidak melarang tradisi ritual Islam dan mitos yang berkembang dalam masyarakat. Selagi tidak keluar dari ajaran Islam. Pada prinsipnya Islam adalah agama damai untuk mengsyiarkan Islam di Indonesia, terutama di tanah Jawa para penyebar Islam memadukan aspek Islam dengan alam pikiran tradisi lama yang sudah melekat pada masyarakat, seperti pengkeramatan acara selamatan merupakan aspek sosio-religius yang sangat sulit dihindari oleh masayarakat Jawa. Sehingga wajar bila Koentjoroningrat memberi nama agama Jawi. Praktek mitologi seperti ini semakin lama semakin kokoh pada masanya namun seiring perkembangan zaman perilaku mitos pudar dengan sendirinya, akan tetapi masih banyak juga masyarakat penganut mitos di masa postmodern saat ini karena mereka menganggap warisan budaya turun temurun yang harus di jaga dan di lestarikan.

\section{Penutup}

Masyarakat postmodern mempercayai mitos dapat mengukuhkan norma-norma yang ada dalam masyarakat karena dipercaya dapat menciptakan kedinamisan dalam masyarakat pendukungnya dan masyarakat umum lainnya sesuai dengan mitos yang berkembang dalam masyarakat tersebut. Mitos di anggap tradisi budaya yang harus di jaga keberlangsungannya di dalam masyarakat. Mitos di anggap penolak bala' dari segala marabahaya dan mendatangkan kedamaian hati dari kekhawatiran ataupun 
kegelisahan yang mereka alami.Dalam perpsektif Islam mitos kemungkinan benar kemungkinan salah, karena segala sesuatu disandarkan pada Sang Pencipta alam semesta ini dan bukan pada hal-hal yang belum jelas kebenarannya. Kebanyakan orang percaya pada mitos itu dikarenakan turun temurun dari keluarga atau masyarakat setempat yang mempercayai kejadian tersebut ataupun ada seseorang yang pernah mengalaminya.Dengan demikian fenomena mitos tidak wajib diyakini kebenarannya apalagi kita sebagai umat Islam yang wajib diyakini adalah kebenaran dari Allah SWT bukan dari hal-hal lain karena semua hal dalam kehidupan ini adalah milik Allah SWT semata bukan milik siapapun, meski dalam Islam tidak melarang umatnya untuk menghormati warisan leluhur kita contohnya di setiap daerah ada mitos yng berlaku di Jawa Tengah ada grebek maulud yaitu untuk memperingati kelahiran Nabi kita Muhammad SAW dan masyarakatpun berebut makanan atau tumpeng yang telah di sediakan oleh pihak kerajaan pada waktu itu yang sampai sekarang setiap tahun juga melaksanakan grebek maulud. Akan tetapi sebagai makhluk ciptaan Allah SWT kita tidak boleh menyakininya bahwa yang membawa berkah adalah tumpeng yang bentuknya besar dan tinggi itu.

\section{DAFTAR PUSTAKA}

Andalas. E.F.Dampak Dan Fungsi Sosial Mitos Mbah Bajing Bagi Spiritual Masyarakat Dusun Kecopokan Kab.malangJawa Timur.Jurnal puitika volume 13 No 1April 2017

Abdul mukti Ro'uf.Postmodern:Dampak Dan Penerapannya Pada Studi Islam.JurnalStudi Keislaman Volume 19 No 1 juli 2019

Budiman.A.Implementasi Postmodern Dalam Pendidikan Ainur Rahman Hidayat. Jurnal Filsafat, Vol. I No. 1, 2017.

Christensen, P.The "Wild West": The life and Death Of A Myth. Southwest Review, 2008.

Darmawan,I.P.A .Pendidikan Kristen di Era Postmodern. STT Simpson, 2016.

Danandjaja.Faktor Indonesia Ilmu Gosip, Dongeng,dan lain-lain. Jakarta:Pustaka Utama Grafiti, 1997.

Hidayat.Menimbang Teori-Teori Sosial Postmodern:Sejarah, Pemikiran, Kritik,Dan Masa Depan Postmodernisme. Journal Unban Sociology.Vol 2 No.1, 2019.

Iswidayati, S., \& Pendahuluan, A. Fungsi Mitos Dalam Kehidupan Sosial Budaya Masyarakat Pendukungnya(The Function of Myth in Social Cultural Life of Its Supporting Community). Harmonia - Journal of Arts Research and Education, 8(2), 180-184. https://doi.org/10.15294/harmonia.v8i2.790 
Ghozali Abd Muqith \&Djohan Effendi.(2009). Merayaka Kebebasan Beragama: Bunga Rampai Menyambut 70 Tahun Djohan Effendi:Buku Kompas Jakarta, 2009.

Danandjaja, J. Folklor Jepang Dilihat dari Kacamata Indonesia.Jakarta: Pustaka Utama Grafiti, 1997.

Leavy,Louis.Manusia Sebuah Misteri Sintesa Filosofis Makhluk Paradoks. Grmedia :Jakarta, 1985.

Maksum, Ali.Pengantar Filsafat.Arrus Media, Jakarta. 2012.

Hidayat. Menimbang Teori-Teori Sosial Postmodern:Sejarah, Pemikiran, Kritik,Dan Masa Depan Postmodernisme. Journal Unban Sociology.Vol 2 No.1, 2019.

Ryan, M. Cultural Studies: A Practical Introduction.Singapore: Blackwell, 2010.

Sugiharjo, I.B.Postmodernisme: Tantangan Bagi Filsafat. Kanius, Yogyakarta, 1996.

Sudrajat. A.Pemikiran Postmodernisme dan Pandangannya Terhadap Ilmu Pengetahuan. Jurnal filsafat Vol 28 No1, 2018.

Wora, Emanuel.Perenialisme: Kritik Atas Modernisme Dan Postmodernisme , Kanisius Yogyakarta, 2006. 